\title{
Correction to: Can addressing inequality unleash economic growth?
}

Lisa D. Cook ${ }^{1} \cdot$ Nela Richardson $^{2} \cdot$ Jim Tankersley $^{3}$

Published online: 15 June 2021

(c) National Association for Business Economics 2021

Correction to: Business Economics (2021) 56:59-66 https://doi.org/10.1057/s11369-021-00215-6

Due to a typesetting mistake, the article was published with an error in one of the author names:

The second author has been corrected to Nela Richardson.

No other changes to the article have been made. We apologise for any inconvenience caused to our readers.
The original article can be found online at https://doi.org/10.1057/ s11369-021-00215-6.

Taken from the transcript of the panel Can Addressing Inequality Unleash Economic Growth? held at the NABE Annual Meeting, October 7, 2020.

\section{Lisa D. Cook}

lisacook@msu.edu

1 Michigan State University, East Lansing, MI, USA

2 ADP Corporation, Roseland, NJ, USA

3 New York Times, Washington, DC, USA
Publisher's Note Springer Nature remains neutral with regard to jurisdictional claims in published maps and institutional affiliations. 